\title{
PODRIJETLO VODSTVA: EVOLUCIJSKI POGLED NA ODNOS VOĐA I NJIHOVIH SLJEDBENIKA
}

\author{
Benjamin Banai \\ Odjel za psihologiju, Sveučilište u Zadru \\ Obala kralja Petra Krešimira IV br. 2, 23000 Zadar \\ benjamin.banai@gmail.com \\ Zvjezdan Penezić \\ Odjel za psihologiju, Sveučilište u Zadru \\ Obala kralja Petra Krešimira IV br. 2, 23000 Zadar \\ zpenezic@unizd.hr
}

\begin{abstract}
Sažetak
Vodstvo je sveprisutno u organizaciji života ljudskih grupa. Istraživanje vođa i vodstva bilo je u središtu interesa raznih društvenih znanosti poput psihologije, ekonomije ili politologije. Dosadašnja literatura iz spomenutih područja uglavnom se bavi opisivanjem kako vodstvo funkcionira i primarno je usmjerena na vođe. U novije vrijeme, pojavljuje se interes za primjenu principa evolucijske psihologije u ovom području te se neki istraživači usmjeravaju na pitanje kako je vodstvo nastalo. Pri tome, važan naglasak se stavlja na adaptivnu vrijednost vodstva od kojega korist imaju svi članovi grupe te u samim teorijskim postavkama bitnu ulogu zauzimaju i sljedbenici vođa, koji u društvu čine većinu. Smatra se da je uspostavljanje odnosa vođa-sljedbenik adaptacija nastala tijekom evolucijske prošlosti koja je bila usmjerena na rješavanje problema koordinacije grupnih zadataka. U ovom preglednom članku prikazat će se tri skupine istraživanja koja idu u prilog navedenim pretpostavkama. Prvo, prikazat će se različiti oblici vodstva i organizacije životinjskih grupa, od insekata do primata. Drugo, opisat će se antropološka istraživanja na plemenima lovaca-sakupljača, čiji je životni stil najsličniji onomu koji su vodili ljudski preci tijekom evolucijske prošlosti. Zatim, prikazat će se niz istraživanja na modernim ljudima, a koja pokazuju da u ljudskim grupama postoji pristranost prema osobinama vođa koje su vjerojatno našim precima signalizirale dobro vodstvo, a koje nisu u skladu s modernim uvjetima života.
\end{abstract}

Ključne riječi: Evolucijska psihologija; evolucijska teorija vodstva, lovci-sakupljači, životinje, evolucijski nesklad, sljedbeništvo

* Članak je napisan uz potporu Stipendije za izvrsnost Filozofskog fakulteta Sveučilišta u Zagrebu. 


\section{UVOD}

Kada se spomene vođa, pojedincima je prva asocijacija visokopozicionirani političar ili rukovoditelj velike kompanije. Ali ako se malo bolje zamislimo, ljudska zajednica je prožeta brojnim formalnim i neformalnim vođama i sljedbenicima tih vođa. Osnovnoškolski učenici imaju predsjednika razreda, sportska momčad ima kapetana, a tvrtke imaju razne razine srednjeg i višeg menadžmenta. Osim toga, i u neformalnim zadacima u kojima sudjeluje više osoba vrlo brzo će se jedna od njih iskristalizirati kao predvodnik, a ostali će se koordinirati oko njenih aktivnosti (Van Vugt i De Cremer, 1999). Znanstvena literatura iz područja ekonomije i politologije primarno, ali i drugih znanosti poput sociologije ili psihologije, sadrži brojne teorije o tome tko i kakav vođa treba biti (Hogan i Kaiser, 2005). Međutim, postoje dva nedostatka u dosadašnjoj literaturi o vodstvu. Prvo, klasične teorije ne rješavaju problem distalnih uzroka pojave vodstva. Drugim riječima, postavlja se pitanje 'Kako vodstvo funkcionira?', a dok istodobno nije odgovoreno na pitanje 'Zašto se vodstvo pojavljuje?' Drugo, dosadašnji pristupi ne uzimaju u obzir sljedbenike kao bitan čimbenik u vodstvu. Ali sljedbenici su itekako bitni. Primjerice, političari će ovisiti o biračima koji se odlučuju njima dati svoj glas, a rukovoditelji će ovisiti o radnoj uspješnosti zaposlenika. Kako bi se odgovorilo na ove nedostatke, istraživači su počeli koristiti adaptacionističku logiku evolucijske psihologije u proučavanju današnjih političara i rukovoditelja, te njihovih birača i podređenih.

Iz evolucijske perspektive, vodstvo je adaptacija formirana u vremenu ljudskih predaka, pomoću koje se i danas koordiniraju zajedničke aktivnosti grupe pojedinaca te koja je ponekad u neskladu s modernim okruženjem (Petersen, 2016; Van Vugt i Ahuja, 2010; Van Vugt, Hogan i Kaiser, 2008). U ovom pregledu prikazat će se glavni nalazi koji podupiru ovu pretpostavku. Bit će prikazani neki primjeri različitih oblika vodstva u životinjskom svijetu, koji upućuju na to da se odnos vođa-sljedbenik pojavio i prije pojave modernih ljudi; te odnos vođa-sljedbenik među modernim plemenima lovaca-sakupljača, koji su najbliži primjer života kakav su vodili ljudski preci u doba pleistocena. S obzirom na to da su psihološke adaptacije evoluirale u pleistocenskom dobu, moguće je da dolazi do nesklada između zahtjeva okoline u kojoj su adaptacije nastale i obilježja moderne okoline. Zbog toga u današnje vrijeme pojedinci ponekad reagiraju na način koji je bio adaptivan našim precima, iako te reakcije danas više ne donose iste adaptivne prednosti. Ovdje će biti prikazan niz nalaza istraživanja koji ilustriraju postojanje evolucijskog nesklada i kod izbora vođe.

\section{Evolucijska teorija vodstva}

Prema evolucijskoj teoriji vodstva (Van Vugt i Ahuja, 2010; Van Vugt i sur., 2008) odnos vođa-sljedbenik je uspostavljan radi lakše koordinacije grupe prilikom ispunjavanja zajedničkih ciljeva, te je evoluirao kroz evolucijsku prošlost ljudskoga 
roda. Prve grupe su vjerojatno nastale slučajno, tako što su se ljudski preci okupljali radi lakše obrane od predatora. No, iz tog okupljanja neke grupe su profitirale jer su koordinirale svoje daljnje aktivnosti te su, ako su bile uspješne, povećavale dobit svakog pojedinog člana grupe. U usporedbi s drugim primatima, ljudske zajednice su bile veće, brojile su oko 150 članova, a prema jednoj od teorija, rast mozga ljudi je povezan s održavanjem kompleksnih odnosa između članova zajednice (Dunbar, 2010). Povećanje grupa omogućuje i podjelu aktivnosti, a prednost podjele je dvojaka: suradnjom se više toga može postići te se smanjuje rizik od rivalstva s drugom grupom zbog bolje koordinacije moguće obrane i napada. Koristeći se logikom evolucijske psihologije (Buss, 2004), može se pretpostaviti da su psihološke adaptacije u podlozi formiranja odnosa vođa-sljedbenik nastale zbog toga što su svim članovima zajednice ljudskih predaka povećavale vjerojatnost preživljavanja i reprodukcije, jer su svi članovi imali više koristi nego što bi svaki član imao da samostalno živi.

Samo provođenje zajedničkih aktivnosti članova grupe ima nekoliko pretpostavki. Prvo, članovi grupe moraju biti svjesni da bi zajedno mogli postići više toga nego ukoliko bi svaki pojedinac samostalno djelovao. Ako bi osobna dobit nekog pojedinca bila veća u slučaju samostalnog djelovanja, ne bi bilo isplativo uključivati se u grupu. Zatim, zajednička aktivnost treba biti koordinirana kako bi bila uspješna. Primjerice, ako je riječ o potrazi za hranom, članovi se trebaju odlučiti na kojoj lokaciji će tragati i kada je najbolje vrijeme za kretanje u potragu (Couzin, Krause, Franks i Levin, 2005). Takav problem je moguće riješiti na način da odluku o smjeru kretanja i polasku donosi pojedinac koji će voditi aktivnost, dok će ga drugi slijediti. Bitno je naglasiti da, ako je vođa kompetentan, odnosno ako ponudi najbolju strategiju za zajedničko traganje, profitirat će svi: vođa će uz pomoć sljedbenika natrag nositi više hrane nego što bi mogao samostalno; a sljedbenici će povećati vjerojatnost pronalaska hrane. Ako bi se ovaj primjer primijenio na druge bitne aktivnosti života ljudskih predaka, poput održavanja unutargrupnih odnosa, borbe protiv drugih grupa, ali i održavanja dobrih odnosa s drugim grupama, može se zaključiti da je evolucija favorizirala dobro vođene grupe spram pojedinačnog života ljudi, grupa bez vođa ili grupa s previše potencijalnih vođa.

Zbog brojnih materijalnih i statusnih pogodnosti istraživanja su uglavnom bila usmjerena na odlike uspješnih vođa. S druge strane, u evolucijskoj teoriji vodstva veliki se naglasak stavlja na sljedbenike. Sljedbenikom najopćenitije možemo nazvati osobu koja koordinira svoje aktivnosti s aktivnostima vođe (Van Vugt i Kurzban, 2007). S obzirom na to da su među ljudima sljedbenici u velikoj većini, to možemo razumijevati kao osnovno stanje u društvenoj hijerarhiji (Van Vugt i Ahuja, 2010) te se isplati usmjeriti pažnju na istraživanje pretpostavljene adaptivne prednosti sljedbeništva. Ljudskim precima se sljedbeništvo isplatilo u tri slučaja: 1 . ljudi nisu posebno snažni, niti imaju posebno razvijene fizičke vještine u odnosu na druge vrste, zbog toga im se isplatilo biti u grupi radi osobne zaštite; 2 . u periodu nesigurnosti isplatilo im se biti blizu drugih osoba koje imaju specifična znanja, poput lokacije skloništa, izvora vode ili pak informaciju o tome koja se hrana ne 
smije jesti jer je otrovna; 3. ako su boravili blizu vođe, mogli su učiti vještine koje su potrebne da postanu vođa te u budućnosti i sami voditi i podići si društveni status (Van Vugt i Ahuja, 2010).

Vodstvo i sljedbeništvo je univerzalno za sve ljudske zajednice (Brown, 1991), kako za moderna industrijalizirana društva, tako i za zajednice lovaca-sakupljača. Sljedbeništvo možemo uočiti već u dojenačkoj dobi, kada bebe oponašaju facijalnu ekspresiju majki, te kada sa tri mjeseca slijede njihov pogled (Hains i Muir, 1996). Osim toga, uspostavljanje odnosa vođa-sljedbenik je brzo i automatsko. Eksperimentalna istraživanja pokazuju da se pojedinci suočeni s nepoznatim zadatkom vrlo brzo koordiniraju i uspostavljaju odnos vođa-sljedbenik kako bi što efikasnije riješili zadatak (Van Vugt i De Cremer, 1999). S obzirom na navedeno, postoje snažni temelji za proučavanje psiholoških mehanizama u podlozi vodstva i sljedbeništva kao adaptacije. U nastavku ovog teksta prikazat će se nalazi istraživanja koji podupiru ovu pretpostavku i koji ilustriraju postojanje vodstva u životinjskom svijetu i unutar modernih plemena lovaca-sakupljača, te pristranosti modernih ljudi prema karakteristikama koje su bile bitne našim precima.

\section{Tko vodi u životinjskom svijetu?}

Možda je najistaknutiji primjer vođe u životinjskom svijetu alfa mužjak koji stoji na čelu hijerarhije dominacije. Kod vrsta koje su organizirane putem ovakve hijerarhije, poput gorila (Fossey, 1972) ili vukova (Peterson, Jacobs, Drummer, Mech i Smith, 2002), dominantnije jedinke su i najčešće fizički veće i jače, imaju veći pristup resursima poput hrane ili ženki, češće zauzimaju bitno mjesto u društvenim mrežama skupina životinja (Krause, Lusseau i James, 2009) te preuzimaju ulogu vođe. Jedna od mogućih uloga vođe je smirivanje sukoba unutar skupine (De Waal, 1996) ili predvođenje drugih članova do izvora hrane (King, Douglas, Huchard, Isaac i Cowlishaw, 2008). No, hijerarhija dominacije je samo jedan od brojnih i mogućih primjera uspostavljanja odnosa vođa-sljedbenik u životinjskom svijetu. Taj odnos će se pojavljivati kod onih vrsta koje se zbog socijalnih ili okolinskih čimbenika kreću, odnosno migriraju zajedno (Johnson, Kays, Blackwell i Macdonald 2002) i to u onim situacijama kada postoji potreba za grupnom koordinacijom poput lova, obrane od predatora, poučavanja, održavanja unutargrupnog mira ili sukoba s drugim životinjskim grupama.

Ponekad se dogodi da jedinke postanu vođe slučajno. Primjerice, neke ribe se kreću u plovama, što im omogućava veću zaštitu te im olakšava pronalaženje hrane. Plove su često organizirane prema jednostavnom pravilu: radi što i riba do tebe, ali se nemojte sudariti. Tijekom prilagođavanja organizaciji plove po ovom pravilu ribe se nasumično pozicioniraju na čelo skupine, a ta pozicija im omogućava veći utjecaj na određivanje smjera zajedničkog kretanja te time postaju vođe (Krause i Ruxton, 2002). U drugim primjerima vođa je jedinka koja ima specifične informacije koje 
prenosi dalje, koja ima izraženu motivaciju, određene temperamentalne crte, a postoje i primjeri demokratskih donošenja odluka među životinjskim vrstama.

Kod pčela postoji primjer poučavanja unutar kojeg možemo također sagledavati ulogu vođe (von Frisch, 1967). Nakon što pronađu hranu, pčele se vraćaju u košnicu i pred svojim rojem izvode kružni ples pomoću kojeg drugim pčelama otkrivaju lokaciju hrane. Pri tome, smjer u kojemu je pčela okrenuta označava položaj hrane u odnosu na sunce, a trajanje plesa označava udaljenost. No ono što je zanimljivo jest da pčele koje su najbolji 'plesači', koje daju najpreciznije upute, ujedno privlače i najviše sljedbenika (Biesmeijer i Seeley, 2005). S druge strane, u plovama skuša (Reebs, 2000) ili jatima gavranova (Wright, Stone i Brown, 2003), pokazano je da jedinke koje imaju informaciju o lokaciji hrane vode svoje grupe u traganju. Pored toga, za vrijeme suše krda slonova se oslanjaju na sjećanja starijih ženki te ih slijede u potrazi za udaljenim izvorima vode na kojima se krdo napajalo u prošlosti (Foley, Petorelly i Foley, 2008).

Uz znanje, motivacija također igra ulogu kod uspostavljanja vodstva u životinjskom svijetu. Tako, primjerice, ribe koje su deprivirane od hrane češće dolaze na čelo plova te imaju veći utjecaj na smjer kretanja (Krause, 1993); trudne ženke zebri (Fischhoff i sur., 2007), lemura (Erhart i Overdorff, 1999) i gibona (Barelli i sur., 2008), koje imaju veće energetske potrebe od ostalih pripadnika krda, češće zauzimaju čelne pozicije u svojim grupama tijekom potrage za hranom.

Osim kratkotrajne motivacije, i stabilne osobine poput temperamenta utječu na pojavu vođe u grupama životinja. Primjerice, kod gupi ribica moguće je razlikovati odvažnije i sramežljivije ribice, koje se razlikuju po tome koliko brzo prilaze novim objektima u akvariju. Kada ribica, bez obzira na njen temperament, bira kome će se priključiti u kretanju i traganju za hranom, veća je vjerojatnost da će se priključiti odvažnim nego sramežljivim ribicima (Harcourt, Sweetman, Johnstone i Manica, 2009). Drugi nalazi upućuju na to da preferencija prema priključivanju odvažnim ribicama proizlaze iz veće vjerojatnosti pronalaska hrane. U jednom istraživanju (Dyer, Croft, Morrell i Krause, 2008) proučavano je traganje za hranom među plovama u kojima su bile samo odvažne, samo sramežljive, ili u plovama koje su bile mješovite s obzirom na temperament ribica. Ribice u mješovitim plovama, i odvažne i sramežljive, pronalazile su veću količinu hrane u usporedbi s drugim skupinama, što ilustrira korist uspostavljanja odnosa vođa-sljedbenik i to za oba organizma.

Naposljetku, kod životinjskih vrsta je također moguće pronaći svojevrstan oblik demokracije, odnosno distribuiranog vodstva. Ovakav oblik vodstva je preferiran u složenim i neizvjesnim uvjetima jer na taj način grupa ima najveće šanse pronalaženja odgovarajućeg rješenja (Conradt i Roper, 2003). Primjer distribuiranog vodstva možemo naći kod babuna koji žive u etiopskim savanama. Ovi majmuni tragaju za hranom u manjim skupinama. Kada kreću u potragu, prvo prolaze kroz proces odlučivanja na koju stranu će krenuti, odnosno tko će voditi potragu. To se odvija na način da jedna jedinka krene u jednom smjeru, zastane i čeka hoće li joj se još netko priključiti. Ako dobije nekoliko sljedbenika, cijela grupa će krenuti u tom smjeru. 
No, ako jedinku nitko ne slijedi, vraća se u grupu i čeka se idući prijedlog za smjer kretanja (Kummer, 1968).

Predstavljeni primjeri različitih oblika vodstva u životinjskom svijetu samo su dio spoznaja koje opisuju formiranje odnosa vođa-sljedbenik kod raznih vrsta, od insekata do primata. Ovi nalazi također upućuju na to da je vodstvo starije od pojave modernih ljudi te da je vjerojatno bilo prisutno u ljudskim grupama od njihova nastanka.

\section{Vodstvo u današnjim plemenima lovaca-sakupljača}

U modernom vremenu postoji manji broj grupa ljudi koji žive kao lovci-sakupljači. Oni su većinom rasprostranjeni u Amazoni, središnjoj i istočnoj Africi te jugoistočnoj Aziji, a njihova se brojnost ubrzano smanjuje. Život koji vode ove zajednice najbliži je načinu života koji su vodili ljudski preci tijekom evolucijske prošlosti te su u današnje vrijeme najbolji pokazatelj društvenih okolnosti u kojima su ljudi evoluirali (von Rueden i Van Vugt, 2015). Proučavanje ovih skupina daje visoku ekološku valjanost nalazima evolucijske psihologije. Postojeći dokazi upućuju na to da je odnos vođa-sljedbenik ljudska univerzalija, drugim riječima, da ga možemo pronaći u svim ljudskim zajednicama (Brown, 1991; Van Vugt, Johnson, Kaiser i O'Gorman, 2008) te se proteže od obitelji, preko plemena, do velikih političkih sustava poput država (Boehm, 2009). Etnografska istraživanja provedena na plemenima Ona iz Južne Amerike, Janomamo iz Amazonske prašume, Enuita s obala Arktika ili Aboridžina sjeverne Australije pokazuju da ova plemena nemaju strogo ustrojstvo zajednice, nemaju jednog jedinstvenog vođu, vodstvo im je distribuirano te se pojavljuje u situacijama kada je potrebno koordinirati grupne aktivnosti (Boehm, 2009). Neke od bitnih grupnih aktivnosti ovih zajednica su, primjerice, skupljanje hrane (Marlowe, 2005), grupni lov (Hill, 1982), razrješavanje unutargrupnih sukoba (Boehm, 2009) ili upravljanje odnosima s drugim grupama bili oni dobri ili ne (Hooper, Kaplan i Boone, 2010; Van Vugt, De Cremer i Janssen, 2007).

U zajednicama lovaca-sakupljača vodstvo je najčešće neformalno i zasnovano na zaslugama (Kelly, 1995). Na taj način vodstvo se uspostavlja s obzirom na kontekst, a vođom postaje pojedinac koji je stručan u svom području (Gronn, 2002). Pojedinac koji vodi lov, vjerojatno neće biti stručan u religijskim obredima, a najspretniji borac vjerojatno neće biti dobar u održavanju dobrih odnosa s drugim grupama. Tako, primjerice, Navajo indijanci imaju posebne vođe za mir, rat, lov, zdravlje i ceremonije (Shepardson, 1963). Cijela grupa ima koristi od uspjeha u aktivnostima zbog toga što kompetentno vodstvo pomaže u ostvarivanju zajedničkih ciljeva. Ako bi grupa bila uspješna u sukobu s drugom grupom, to bi im omogućilo više resursa poput polaganja prava na nove teritorije (Keeley, 1997), a uspjeh u zajedničkom lovu značio bi veće količine mesa koje se dijeli unutar cijele grupe (Kelly, 1995). 
Međutim, kada se radi o izboru vođa, bitno je za naglasiti da evolucija nije favorizirala despotskog vođu koji bi dominacijom sebi priskrbljivao resurse nauštrb grupe. Da bi se zaštitili od toga, sljedbenici su razvili razne strategije. Boehm (2009) navodi da je, primjerice, tračanje vođe sveprisutno u zajednicama lovaca-sakupljača ako se vođa ne ponaša po pravilima grupe. Osim toga, vođe su izloženi otvorenom kriticizmu ako bi drugom članu grupe pokušali dati izravnu zapovijed (Iban pleme, Filipini), nadglasani ako bi postali previše asertivni (Shavante, Južna Amerika) ili prekoreni ako požele previše moći za sebe. Članovi !Kung plemena u Kalahari pustinji preventivno ismijavaju uspješne lovce i umanjuju vrijednost njihova ulova kako se oni ne bi umislili i pomislili da su vrjedniji od drugih. Drugi oblik zaštitnog mehanizma od despotskog vođe je stvaranje koalicija (Petersen, 2016). Prema tome, višerangirani pojedinac može biti u problemima ako ne ispunjava ciljeve grupe te se više podređenih može udružiti protiv njega i formirati koaliciju. Na sličnom principu temelji se i moderna demokracija unutar koje je vodstvo države nadgledano, a birači smatraju vođu legitimnim ako ispunjava njihove interese (Bøggild i Petersen, 2016).

Iz perspektive evolucijske psihologije, dobrovoljni društveni odnosi se razvijaju ako svi dionici putem njih mogu povećati svoj reproduktivni uspjeh, odnosno ako se povećava vjerojatnost prijenosa gena na iduće naraštaje, bilo putem razmnožavanja ili putem potpore reprodukciji svojih srodnika (Tooby i Cosmides, 1992; 2005). Vođe svojim sljedbenicima daju pristup javnim dobrima koji se dijele između pripadnika grupe, dok im sljedbenici uzvraćaju pružajući im prestiž (Price i Van Vugt, 2014; 2015). Pri tome, prestiž je konstrukt odvojen od dominantnosti, te opisuje društveni status koji sljedbenici dobrovoljno dodjeljuju vođi od kojega imaju koristi, dok je dominantnost status koji je ostvaren pod pritiskom i prijetnjama drugima (Henrich i Gil-White, 2001). S druge strane, vodstvo u malim zajednicama može biti prilično skupocjeno za sljedbenike. Primjerice, lovci iz Kalahari pustinje znaju loviti plijen između tri i šest sati dnevno, prilikom čega prelaze udaljenost između 20 i 35 kilometara na visokoj temperaturi, teškom terenu is malom količinom vode (Liedenberg, 2006). Usprkos visokoj cijeni, smatra se da u ovakvom obliku odnosa vođa-sljedbenik, sljedbenici i dalje profitiraju povećavajući svoj ukupni reproduktivni uspjeh, a vođe iz ovog odnosa profitiraju osiguravajući si društveni status (Price, 2003; 2006). Pojedinci s većim društvenim statusom ne moraju nužno imati direktne materijalne koristi od svoga društvenoga položaja. Na primjer, vođe u malim zajednicama imaju i veću ukupnu reproduktivnu uspješnost. Tako se pokazuje da je društveni status privlačan i ženama koje biraju partnera (Li, 2007), ali i roditeljima koji traže partnera za svoju kćer (Kelly, 1995). To rezultira time da pojedinci s visokim društvenim statusom u zajednici lovaca-sakupljača imaju ukupno više seksualnih partnerica te stupaju u odnose s plodnijim ženama (von Rueden, Gurven i Kaplan, 2008; 2010).

S obzirom na navedeno, postavlja se pitanje tko se, iz perspektive sljedbenika, percipira kao prikladna osoba za vođu? Van Vugt i suradnici (2008) opisuju naj- 
vjerojatnijeg vođu kao 'Velikog čovjeka' (Big man,) što je naziv koji se pojavljuje u većem broju plemena. Ovdje je riječ o vještom i inteligentnom muškarcu, često najvještijem ratniku u plemenu, koji posjeduje svojevrsnu karizmu te je uspješan u ostvarivanju ciljeva koji su zajednički za cijelu grupu. Iako su ovakve zajednice egalitarne, etnografska istraživanja navode da su vođe češće muškarci nego žene (Johnson i Earle, 1987; Vandermassen, 2008), što ne čudi s obzirom na to da su najvažnije aktivnosti koje zahtijevaju grupnu koordinaciju poput lova ili borbe, fizički prilično zahtjevne. Zbog selekcijskih pritisaka, muškarci su u prosjeku viši i snažniji od žena (Gray i Wolfe, 1980) te je zbog toga vjerojatnije da će biti uspješni u ovim aktivnostima. Drugo potencijalno objašnjenje ovog nerazmjera u broju žena na položaju vođa tradicionalna je raspodjela poslova unutar koje su žene ulagale znatno više vremena u podizanje potomstva te nisu sudjelovale u stvaranju širih društvenih mreža van šire obitelji. Muškarci su svoje društvene mreže širili zajedničkim grupnim aktivnostima, gdje su imali priliku stjecati utjecaj i izvan svoje obitelji, za razliku od žena (von Rueden i Van Vugt, 2015). Bitno je još naglasiti da žene rijetko imaju direktnu vodeću ulogu u plemenima lovaca-sakupljača, no da često imaju indirektan utjecaj na politička pitanja, posebice u poliginim društvima (Yanca i Low, 2004). Idući bitan čimbenik je dob potencijalnog vođe. Istraživanja pokazuju da stariji članovi češće postaju vođe, a to se objašnjava činjenicom da su tijekom života uspjeli akumulirati više znanja koje mogu primijeniti u različitim situacijama (Baltes i Smith, 1990; Schniter, Gurven, Kaplan, Wilcox i Hooper, 2015). Ipak, mlađi članovi su preferirani za vođu kada je zadatak fizički zahtjevniji (von Rueden, Gurven, Kaplan i Stieglitz, 2014). Osim dobi, čini se da je i fizička snaga bitna za status vođe u zajednicama lovaca-sakupljača. Fizička snaga može upućivati na kompetentnost i veću uspješnost u bitnim aktivnostima za grupu, poput lova ili borbe (Apicella, 2014). Osim toga, u Tsimane plemenu je primijećeno da su muškarci koji vode sastanke zajednice u prosjeku veći i snažniji od ostalih, a u eksperimentalno kontroliranim uvjetima je pokazano da su grupe lovaca-sakupljača vođene od strane većih i snažnijih muškaraca bile uspješnije u obavljanju zadataka (von Rueden i sur., 2014). Osim toga, veći i snažniji muškarci su i više zastrašujući te mogu imati veći utjecaj na druge. Navedeno se u egalitarnim zajednicama cijeni ako se neki pojedinci odmetnu od društvenih normi, te trebaju biti kažnjeni ili prekoreni (von Rueden i Gurven, 2012).

\section{Hipoteza evolucijskog nesklada}

Život lovaca-sakupljača najbliži je primjer života koji su vodili ljudski preci u periodu evolucijske prošlosti i proučavanje ovih skupina može dati uvid u društveno okruženje unutar kojega su nastale današnje psihičke adaptacije. Evolucija se, gledano u terminima ljudskoga života, odvija jako sporo, a procjenjuje se da je potrebno između 1,000 i 10,000 generacija da mutacija koja je korisna u preživ- 
ljavanju i reprodukciji postane rasprostranjena u populaciji. U prilog tomu ide i procjena da svaka osoba nosi između 100 i 200 mutacija, što predstavlja manje od $0.001 \%$ genoma (Xue i sur., 2009). Za ljude bi to značilo da je potrebno otprilike 20,000 do 200,000 godina da pojedina korisna mutacija postane rasprostranjena u populaciji. S obzirom na to da se kultura i čovjekova okolina mijenjaju znatno većom brzinom od genoma, ne može se uvijek očekivati da će evolucijske adaptacije biti u skladu s modernim okruženjem (Tooby i Cosmides, 1990), što se naziva evolucijskim neskladom. Možda najpoznatiji primjer evolucijskog nesklada je preferencija modernih ljudi prema slatkoj i masnoj hrani. Ova hrana je puna kalorija i daje mnogo energije, no našim precima je bila teško dostupna, zbog čega su konzumirali velike količine ako bi je našli (Nesse i Williams, 1994). Preferencija prema ovim okusima je ostala i u modernom dobu, uz razliku što je sada ova hrana široko dostupna, a ljudski organizam nije prilagođen za velik unos šećera i masti. To na kraju rezultira širokim spektrom zdravstvenih problema. Ovakvu logiku razmišljanja može se primijeniti i na organizaciju života u ljudskim društvima. Tek nakon prve poljoprivredne revolucije koja se dogodila prije otprilike 13,000 godina, ljudi počinju živjeti u većim grupama (Foley, 1995), a prve države nastaju u Mezopotamiji prije otprilike 5000 godina (Petersen i Skaaning, 2010). S obzirom na to da je red Homo star oko 2.5 milijuna godina, te da su ljudi većinu tog vremena proveli u malim zajednicama koje su brojile između 25 i 150 članova i u kojima nije bila izražena hijerarhija, može se zaključiti da moderni ekonomski i politički sustavi predstavljaju evolucijsku novinu (Petersen, 2015). Ako se odnos vođa-sljedbenik uspostavlja po načelima koja su bila bitna našim precima iz pleistocena, može se očekivati da neki aspekti tog odnosa predstavljaju nesklad s modernim okruženjem te je moguće da i danas biramo vođe na temelju fizičkih i psihičkih karakteristika koji su nekada signalizirali uspješno vodstvo (Van Vugt i sur., 2008). U modernom svijetu, posao vođe uglavnom ne zahtijeva fizički kompetentnije pojedince, stoga bi hipoteza nesklada mogla objasniti neke osobine vođa u modernom vremenu, poput toga da ljudi preferiraju snažne (Sell, Tooby i Cosmides, 2009) i visoke muškarce (Stulp, Buunk, Verhulst i Pollet, 2013) za svoje vođe.

\section{Preferencije prema karakteristikama vođa u modernom dobu}

Moguće je povući niz paralela s odabirom vodstva u malim zajednicama lovaca sakupljača i s najčešćim vođama u modernom industrijaliziranom svijetu. Ako imaju izbora, ljudi će biti skloniji vođama koje su sami odabrali nego onima koji su im nametnuti (Van Vugt, Jepson, Hart i De Cremer, 2004), a pojedincima koji su spremni alocirati sredstva i sposobnosti u svrhu grupnih interesa dodjeljivat će veći društveni status (Hardy i Van Vugt, 2006; Willer, 2009). Moguće je da je zbog toga demokracija preferirani sustav organiziranja države te pojedinci koji žive u demokratskim državama procjenjuju da imaju najveću subjektivnu dobrobit (Diener i 
Seligman, 2004). Poznato je da ljudi generalno pozitivnije vrednuju članove svoje grupe spram članova drugih grupa (Tajfel, Biling, Bundy i Flament, 1971), a istraživanja pokazuju da ćemo preferirati vođu koji nam je sličan čak i kada je manje sposoban od drugih kandidata (Van Vugt i De Cremer, 1999). Osim toga, pojedinci će preferirati i vođu s čijim se svjetonazorom mogu poistovjetiti. Primjerice, oni restriktivne seksualnosti preferirali su vođe koji su bili za ograničavanje seksualnih sloboda (Kurzban, Dukes i Weeden, 2010). Ovi nalazi mogli bi poduprijeti pretpostavku da je odnos vođa-sljedbenik evoluirao u malim zajednicama u kojima su se svi članovi poznavali te koje nisu imale česte kontakte s drugim grupama.

Kako je ranije spomenuto, dob vođe je također bitan čimbenik i čini se da je preferirana dob vođe kontekstualno uvjetovana. U profesijama koje su zasnovane na specijaliziranom znanju (primjerice, sveučilišni profesori), dob pozitivno korelira s percipiranim statusom i sposobnostima vodstva. Nasuprot tome, ovakva korelacija nije pronađena za poslove koji zahtijevaju veliku snagu i energiju, poput časnika $u$ vojsci (Bass i Bass, 2009). Drugi nalazi pokazuju da preferencije prema vođi ovise i o stabilnosti prilika u okolini. Tako će mlađi vođe biti preferirani u nestabilnim vremenima u kojima se organizacije moraju susretati s novim izazovima, dok će u stabilnim vremenima u kojima je dovoljno održavati postojeće stanje biti preferirani stariji vođe (Spisak, Grabo, Arvey i Van Vugt, 2014). Ovi nalazi imaju uporišta i u poslovnom svijetu. Primjerice, prosječna dob direktora kompanija s Fortune 500 liste najuspješnijih korporacija je 55 godina, dok je prosječna dob direktora internetskih kompanija iz Silicijske doline, među kojima je visoka inovativnost, 31 godina (Korunka, Frank, Lueger i Mugler, 2003).

$\mathrm{S}$ obzirom na to da su uspješni vođe $u$ doba naših evolucijskih predaka morali biti uspješni u fizički zahtjevnim zadacima, može se očekivati da će i danas postojati preferencije prema određenim fenotipovima, a istraživanja to i podupiru. Za početak, čini se da visina potencijalnih vođa igra ulogu. Istraživanje u kojemu je provjeravana povezanost između visine predsjedničkih kandidata i uspjeha na američkim izborima pokazalo je da viši kandidati imaju veće šanse pobjede na izborima, da razlika u visini dva kandidata objašnjava $15 \%$ varijance podrške birača te da viši kandidat ima veće šanse za reizbor (Stulp i sur., 2013). Velika meta-analiza (Judge i Cable, 2004) pokazala je da je visina povezana i s radnom uspješnosti: viši ljudi su bili na višim položajima u kompanijama i zarađivali su više, a ovaj efekt je bio izraženiji za muškarce nego za žene.

Nadalje, ljudi su osobito osjetljivi na prepoznavanje lica. Lica su spolno dimorfna karakteristika ljudskog tijela (Perrett i sur., 1998) te je na temelju lica moguće donositi zaključke o muževnosti ili ženstvenosti neke osobe. Izgled lica također može odavati znakove pubertalnog testosterona te je na taj način posredno indikator tjelesne snage (Sell i sur., 2009). U jednom istraživanju (Mueller i Mazur, 1996) ispitanici su procjenjivali dominantnost studenata vojne akademije na temelju njihove fotografije. Rezultati su pokazali da su oni studenti koji su procijenjeni dominantnijima postigli veći uspjeh u daljnjoj karijeri. Istraživanja pokazuju da 
ljudi preferiraju vođe koji imaju muževnija lica (Little, Burriss, Jones i Roberts, 2007; Carpinella, Hehman, Freeman i Johnson, 2016). Osim toga, ljudi su skloni na temelju lica zaključivati o kompetentnosti političkih kandidata. Na temelju izlaganja fotografiji političkog kandidata od samo jedne sekunde ispitanici su bili skloni formirati stav o kompetentnosti političkog kandidata, a izmjerene percepcije kompetentnosti su bile značajno povezane s rezultatom održanih izbora (Todorov, Mandisodza, Goren i Hall, 2005). Osim toga, ljudi generalno pokazuju sklonosti prema atraktivnijim vođama (Anderson, John, Keltner i Kring, 2001, Grammer, Fink, Møller i Thornhill, 2003, White, Kenrick i Neuberg, 2013), a autori komentiraju da privlačnost na temelju lica upućuje na dobro zdravlje i genetsku kvalitetu. Smatra se da bi ljudi trebali biti posebno osjetljivi na znakove koji upućuju na dobro zdravlje onih s kojima smo najintimniji (npr. bračni partner) ili onih o kojima najviše ovisimo (npr. vođa) (White i sur., 2013).

Osim lica ljudi su osjetljivi i na dubinu glasa, što je također spolno dimorfna karakteristika koja je povezana s razinama spolnih hormona. Dublji glas je percipiran kao muževniji. Pokazalo se da ljudi biraju političke kandidate s dubljim odnosno muževnijim glasovima u eksperimentalno kontroliranim uvjetima (Tigue, Borak, O'Connor, Schandl i Feinberg, 2012), a isti nalaz je dobiven i u istraživanjima u kojima je dubina glasa predsjedničkih kandidata iz različitih država povezana s ishodom izbora (Banai, Pavela Banai i Bovan, 2017; Banai, Laustsen, Pavela Banai i Bovan, 2018; Pavela Banai, Banai i Bovan, 2017). Osim toga, dublji glas preferiraju i muškarci i žene i to kod muških i kod ženskih političkih kandidata (Klofstad, 2016). U poslovnom svijetu pokazano je da direktori s dubljim glasovima upravljaju kompanijama s većim zaradama, te da njihov mandat traje duže (Mayew, Parsons i Venkatachalam, 2013).

U svijetu lovaca-sakupljača ne postoji jedan jedinstven vođa, već osobe različitih kompetencija postaju vođe ovisno o zahtjevima zadatka. Slične kontekstualno specifične preferencije pokazuju i ljudi u industrijaliziranim zemljama prilikom izbora svojih vođa (Price i Van Vugt, 2015). Primjerice, birači će preferirati vođe muževnijeg izgleda ako postoji prijetnja sukobom te ženstvenijeg izgleda u mirnodopskom razdoblju (Laustsen i Petersen, 2015; Little i sur., 2007; Spisak i sur., 2012). Jednako tako, vođe dubljeg glasa su preferirane pod prijetnjom sukoba $\mathrm{s}$ drugim grupama (Tigue i sur., 2012). S obzirom na to da su grupe lovaca-sakupljača egalitarne i da imaju mehanizme pomoću kojih suzbijaju moguću pojavu dominacije (Boehm, 2009), smatra se da je preferencija prema dominantnim vođama u situacijama prijetnje sukobom evolucijski kompromis, pri čemu se članovi grupe izlažu riziku eksploatacije grupnih resursa u svrhu veće vjerojatnosti obrane predvođene dominantnim vođom (Von Rueden i sur., 2014). U skladu s time, dominantni vođe (odnosno politički kandidati s muževnim licima i glasovima) su preferirani i kod birača konzervativne političke ideologije, koji su skloniji percipirati svijet kao opasno i prijeteće mjesto (Laustsen i Petersen, 2016, Banai i sur., 2018). Potencijalna prijetnja bolestima iz okoline još je jedan bitan čimbenik koji ima utjecaja 
na preferenciju prema fizičkim karakteristikama vođa. White i suradnici (2013) su pokazali da birači u okruzima u kojima je niža očekivana životna dob biraju fizički atraktivnije političke kandidate, a to su interpretirali pomoću bihevioralnog imunološkog sustava, koji je pretpostavljeni mehanizam izbjegavanja patogena iz okoline (Schaller, 2006). S obzirom na to da postoji povezanost između atraktivnosti i zdravlja (Rhodes, 2006), smatra se da na ovaj način birači pokušavaju spriječiti unos patogena u svoju grupu.

\section{ZAKLJUČAK}

Ako je ljudski um oblikovan za uspješno rješavanje problema u okolini naših predaka, može se očekivati da će se zbog nesklada današnje i ondašnje okoline pojavljivati preferencije prema nekim karakteristikama vođa koje su nekada bile značajne, a danas nisu. Navedeni su brojni primjeri u kojima je pokazano da moderni sljedbenici i dalje preferiraju vođe s određenim tjelesnim karakteristikama, što upućuje na evolucijski nesklad. Tooby i Cosmides (1990) vide ljudski um kao izvršitelja adaptacija, koji cijelo vrijeme pretražuje naš okoliš i ako se pojave znakovi koji su u doba naših predaka lovaca-sakupljača povećavali vjerojatnost preživljavanja i reprodukcije, aktivira adaptacije i usmjerava ponašanje. U današnje vrijeme i dalje postoje takvi znakovi, iako su se okolina i način života uvelike promijenili. Ljudi će, na primjer, i dalje imati veliku želju unijeti što više moguće masne i slatke hrane u organizam, iako znaju za potencijalne zdravstvene opasnosti i znaju da će im ista hrana biti dostupna i za idući obrok. Jednako tako, ljudi će birati muževnije i snažnije vođe država iako poslovi koje će oni obavljati ne zahtijevaju direktno fizičko suočavanje i ne uključuju upotrebu snage. Jedna od perspektiva u interpretaciji ovakvih nalaza je da su ljudi iracionalni. No, druga perspektiva, ona adaptacionistička, jest da su spomenute pristranosti evoluirale jer su bile funkcionalne u okružju pleistocenskih plemena lovaca-sakupljača. Kada se takva logika razmišljanja pojavi kao odgovor na problem koordinacije grupne aktivnosti u modernom okruženju u kojemu ljudi žive u velikim zajednicama, rezultat je donošenje automatskog i pristranog zaključka koji se samo na prvu može činiti iracionalnim, no moguće je da dolazi do evolucijskog nesklada.

\section{LITERATURA}

Anderson, C., John, O. P., Keltner, D. i Kring, A. M. (2001). Who attains social status? Effects of personality and physical attractiveness in social groups. Journal of personality and social psychology, 81(1), 116-132. doi: 10.1037/0022-3514.81.1.116

Apicella, C. L. (2014). Upper-body strength predicts hunting reputation and reproductive success in Hadza hunter-gatherers. Evolution and Human Behavior, 35(6), 508-518. doi: 10.1016/j.evolhumbehav.2014.07.001 
Ballew, C.C. i Todorov, A. (2007). Predicting political elections from rapid and unreflective face judgments. Proceedings of the National Academy of Sciences, 104(46), 1794817953. doi: 10.1073/pnas.0705435104

Baltes, P.B. i Smith, J. (1990). Towards a psychology of wisdom and its ontogenesis. U: R.J. Sternberg (Ur.), Wisdom, its nature, origins, and development (str. 87-120). Cambridge, United Kingdom: Cambridge University Press. doi: 10.1017/cbo9781139173704.006

Banai, B., Laustsen, L., Pavela Banai, I. i Bovan, K. (2018). Presidential, But Not Prime Minister, Candidates With Lower Pitched Voices Stand a Better Chance of Winning the Election in Conservative Countries. Evolutionary Psychology, 16(2), 1474704918758736. doi: $10.1177 / 1474704918758736$

Banai, B., Pavela Banai, I. i Bovan, K. (2017). Candidates' voice in political debates and the outcome of presidential elections. U: I. Burić (ur.), 20th Psychology Days in Zadar; Book of Selected Proceedings (str. 33-39). Zadar: Sveučilište u Zadru.

Barelli, C., Boesch, C., Heistermann, M. i Reichard, U. H. (2008). Female white-handed gibbons (Hylobates lar) lead group movements and have priority of access to food resources. Behaviour, 145(7), 965-981.

Biesmeijer, J. C. i Seeley, T. D. (2005). The use of waggle dance information by honey bees throughout their foraging careers. Behavioral Ecology and Sociobiology, 59(1), 133 142. doi: 10.1007/s00265-005-0019-6

Boehm, C. (2009). Hierarchy in the forest: The evolution of egalitarian behavior. Cambridge, MA: Harvard University Press.

Bøggild, T. i Petersen, M. B. (2016). The evolved functions of procedural fairness: An adaptation for politics. U: T.K. Shackelford i R.D. Hansen (ur.), The evolution of morality (pp. 247-276). New York, NY: Springer International Publishing. doi: 10.1007/978-3319-19671-8_12

Brown, D. E. (1991). Human universals. New York, NY: McGraw-Hill.

Buss, D. M. (2004). Evolutionary psychology: The new science of the mind. Boston, MA: Allyn and Bacon.

Carpinella, C. M., Hehman, E., Freeman, J. B. i Johnson, K. L. (2016). The gendered face of partisan politics: Consequences of facial sex typicality for vote choice. Political Communication, 33(1), 21-38. doi: 10.1080/10584609.2014.958260

Conradt, L. i Roper, T. J. (2003). Group decision-making in animals. Nature, 421(6919), 155-158. doi: 10.1038/nature01294

Couzin, I. D., Krause, J., Franks, N. R. i Levin, S. A. (2005). Effective leadership and decision-making in animal groups on the move. Nature, 434(7025), 513-516. doi: 10.1038/ nature 03236

De Waal, F. B. (1996). Good natured. Cambridge, MA: Harvard University Press.

Diener, E. i Seligman, M. E. (2004). Beyond money: Toward an economy of well-being. Psychological science in the public interest, 5(1), 1-31. doi: 10.1007/978-90-481-23506_9

Dunbar, R. (2010). How many friends does one person need?: Dunbar's number and other evolutionary quirks. London, United Kingdom: Faber \& Faber. 
Dyer, J. R., Croft, D. P., Morrell, L. J. i Krause, J. (2008). Shoal composition determines foraging success in the guppy. Behavioral Ecology, 20(1), 165-171. doi: 10.1093/beheco/arn129

Erhart, E. M. i Overdorff, D. J. (1999). Female coordination of group travel in wild Propithecus and Eulemur. International Journal of Primatology, 20(6), 927-940. doi: 10.1023/A:1020830703012

Fischhoff, I.R., Sundaresan, S.R., Cordingley, J., Larkin, H.M., Sellier, M.J. i Rubenstein, D.I. (2007). Social relationships and reproductive state influence leadership roles in movements of plains zebra, Equus burchellii. Animal Behavior, 73(5), 825-831. doi: 10.1016/j.anbehav.2006.10.012

Foley, C., Pettorelli, N. i Foley, L. (2008). Severe drought and calf survival in elephants. Biology Letters, 4(5), 541-544. doi: 10.1098/rsbl.2008.0370

Foley, R. (1995). The adaptive legacy of human evolution: A search for the environment of evolutionary adaptedness. Evolutionary Anthropology: Issues, News, and Reviews, 4(6), 194-203. doi: 10.1002/evan.1360040603

Fossey, D. (1972). Vocalizations of mountain gorilla (Gorilla-Gorilla-Beringei). Animal Behaviour, 20(1), 36-53. doi: 10.1016/s0003-3472(72)80171-4

Grammer, K., Fink, B., Møller, A. P. i Thornhill, R. (2003). Darwinian aesthetics: sexual selection and the biology of beauty. Biological Reviews, 78(3), 385-407. doi: 10.1017/ s1464793102006085

Gray, J. P. i Wolfe, L. D. (1980). Height and sexual dimorphism of stature among human societies. American Journal of Physical Anthropology, 53(3), 441-456. doi: 10.1002/ ajpa. 1330530314

Gronn, P. (2002). Distributed leadership as a unit of analysis. The Leadership Quarterly, 13(4), 423-451. doi: 10.1016/s1048-9843(02)00120-0

Hains, S. M. i Muir, D. W. (1996). Infant sensitivity to adult eye direction. Child Development, 67(5), 1940-1951. doi: 10.2307/1131602

Harcourt, J. L., Sweetman, G., Johnstone, R. A. i Manica, A. (2009). Personality counts: the effect of boldness on shoal choice in three-spined sticklebacks. Animal Behaviour, 77(6), 1501-1505. doi: 10.1016/j.anbehav.2009.03.004

Hardy, C. L. i Van Vugt, M. (2006). Nice guys finish first: The competitive altruism hypothesis. Personality and Social Psychology Bulletin, 32(10), 1402-1413. doi: $10.1177 / 0146167206291006$

Henrich, J. i Gil-White, F. J. (2001). The evolution of prestige: freely conferred status as a mechanism for enhancing the benefits of cultural transmission. Evolution and Human Behavior, 22(3), 165-196. doi: 10.1016/s1090-5138(00)00071-4

Hill, K. (1982). Hunting and human evolution. Journal of Human Evolution, 11(6), 521-544. doi: 10.1016/s0047-2484(82)80107-3

Hogan, R. i Kaiser, R. B. (2005). What we know about leadership. Review of General Psychology, 9(2), 169 - 180. doi: 10.1037/1089-2680.9.2.169

Hooper, P., Kaplan, H. i Boone, J. (2010). A theory of leadership in human cooperative groups. Journal of Theoretical Biology, 265(4), 633-646. doi: 10.1016/j.jtbi.2010.05.034

Johnson, A.W. i Earle, T. (1987). The Evolution of Human Societies. Stanford, CA: Stanford University Press. 
Johnson, D.D.P., Kays, R., Blackwell, P.G. i Macdonald, D.W. (2002). Does the resource dispersion hypothesis explain group living?. Trends in Ecology and Evolution, 17(12), 563-570. doi: 10.1016/s0169-5347(02)02619-8

Judge, T. A. i Cable, D. M. (2004). The effect of physical height on workplace success and income: preliminary test of a theoretical model. Journal of Applied Psychology, 89(3), 428-441. doi: 10.1037/0021-9010.89.3.428

Keeley, L. H. (1997). War before civilization. Oxford, United Kingdom: Oxford University Press.

Kelly, R. L. (1995). The Foraging Spectrum: Diversity in Hunter-Gatherer Lifeways. Washington, D.C.: Smithsonian.

King, A.J., Douglas, C.M.S., Huchard, E., Isaac, N.J.B. i Cowlishaw, G. (2008). Dominance and affiliation mediate despotism in a social primate. Current Biology, 18(23), 1833-1838. doi: 10.1016/j.cub.2008.10.048

Klofstad, C. A. (2016). Candidate voice pitch influences election outcomes. Political Psychology, 37(5), 725-738. doi: 10.1111/pops.12280

Knauft, B. M. (1987). Reconsidering Violence in Simple Human Societies: Homicide among the Gebusi of New Guinea. Current Anthropology, 28(4), 457-500. doi: 10.1086/203549

Korunka, C., Frank, H., Lueger, M. i Mugler, J. (2003). The entrepreneurial personality in the context of resources, environment, and the startup process: A configurational approach. Entrepreneurship: Theory and Practice, 28(1), 23-42. doi: 10.1111/15408520.00030

Krause, J. (1993). The Relationship between foraging and shoal position in a mixed shoal of roach (Rutilus-Rutilus) and chub (Leuciscus-Cephalus)- a field-study. Oecologia, 93(3), 356-359. doi: 10.1007/bf00317878

Krause, J. i Ruxton, G. D. (2002). Living in groups. Oxford, United Kingdom: Oxford University Press.

Krause, J., Lusseau, D. i James, R. (2009). Animal social networks: an introduction. Behavioral Ecology and Sociobiology, 63(7), 967-973.

Kummer, H. (1968). Social organization of hamadryas baboons. Chicago, IL: University of Chicago Press.

Kurzban, R., Dukes, A. i Weeden, J. (2010). Sex, drugs and moral goals: Reproductive strategies and views about recreational drugs. Proceedings of the Royal Society B: Biological Sciences, 277(1699), 3501-3508. doi: 10.1098/rspb.2010.0608

Laustsen, L. i Petersen, M. B. (2015). Does a competent leader make a good friend? Conflict, ideology and the psychologies of friendship and followership. Evolution and Human Behavior, 36(4), 286-293. doi: 10.1016/j.evolhumbehav.2015.01.001

Laustsen, L. i Petersen, M. B. (2016). Winning faces vary by ideology: How nonverbal source cues influence election and communication success in politics. Political Communication, 33(2), 188-211. doi: 10.1080/10584609.2015.1050565

Li, N. P. (2007). Mate preference necessities in long-and short-term mating: People prioritize in themselves what their mates prioritize in them. Acta Psychologica Sinica, 39(3), 528.

Liebenberg, L. (2006). Persistence hunting by modern hunter-gatherers. Current Anthropology, 47(6), 1017-1026. doi: 10.1086/508695 
Little, A. C., Burriss, R. P., Jones, B. C. i Roberts, S. C. (2007). Facial appearance affects voting decisions. Evolution and Human Behavior, 28(1), 18-27. doi: 10.1016/j.evolhumbehav.2006.09.002

Marlowe, F. W. (2005). Hunter-gatherers and human evolution. Evolutionary Anthropology: Issues, News, and Reviews, 14(2), 54-67. doi: 10.1002/evan.20046

Mayew, W. J., Parsons, C. A. i Venkatachalam, M. (2013). Voice pitch and the labor market success of male chief executive officers. Evolution and Human Behavior, 34(4), $243-$ 248. doi: 10.1016/j.evolhumbehav.2013.03.001

Mueller, U. i Mazur, A. (1996). Facial dominance of West Point cadets as a predictor of later military rank. Social Forces, 74(3), 823-850. doi: 10.2307/2580383

Nesse, R. M. i Williams, G. C. (1994). Why we get sick: the new science of Darwinian medicine. New York, NY: Vintage.

Pavela Banai, I., Banai, B. i Bovan, K. (2017). Vocal characteristics of presidential candidates can predict the outcome of actual elections. Evolution and Human Behavior, 38(3), 309-314. doi: 10.1016/j.evolhumbehav.2016.10.012

Perrett, D. I., Lee, K. J., Penton-Voak, I., Rowland, D., Yoshikawa, S., Burt, D. M., ... i Akamatsu, S. (1998). Effects of sexual dimorphism on facial attractiveness. Nature, 394(6696), 884-887. doi: 10.1038/29772

Petersen, M. B. (2015). Evolutionary Political Psychology: On the Origin and Structure of Heuristics and Biases in Politics. Advances in Political Psychology, 36(1), 45 - 78. doi: 10.1111/pops. 12237

Petersen, M. B. i Skaaning, S. E. (2010). Ultimate Causes of State Formation: The Significance of Biogeography, Diffusion, and Neolithic Revolutions. Historical Social Research, 35(3), 200-226.

Petersen, M.B. (2016). Evolutionary political psychology. U: D.M. Buss (ur.), The handbook of Evolutionary Psychology, Sexcond edition, Volume 2: Integrations (str. 1084 - 1102). Hoboken, NJ: Wiley. doi: 10.1002/9781119125563.evpsych247

Peterson, R.O., Jacobs, A.K., Drummer, T.D., Mech, L.D. i Smith, D.W. (2002). Leadership behavior in relation to dominance and reproductive status in gray wolves, Canis lupis. Canadian Journal of Zoology, 80(8), 1405-1412. doi: 10.1139/z02-124

Price, M. E. (2003). Pro-community altruism and social status in a Shuar village. Human Nature, 14(2), 191-208. doi: 10.1007/s12110-003-1003-3

Price, M. E. (2006). Judgments about cooperators and freeriders on a Shuar work team: An evolutionary psychological perspective. Organizational Behavior and Human Decision Processes, 101(1), 20-35. doi: 10.1016/j.obhdp.2006.06.001

Price, M. E., i Van Vugt, M. (2014). The evolution of leader-follower reciprocity: the theory of service-for-prestige. Frontiers in human neuroscience, 8, 1-17. doi: 10.3389/ fnhum.2014.00363

Price, M. E., i Van Vugt, M. (2015). The service-for-prestige theory of leader-follower relations: A review of the evolutionary psychology and anthropology literatures. U: S.M. Colarelli i R.D. Arvey (ur.), Biological Foundations of Organizational Behavior (str. 169-201). Chicago, IL: The University of Chicago Press.

Reebs, S. G. (2000). Can a minority of informed leaders determine the foraging movements of a fish shoal?. Animal behaviour, 59(2), 403-409. doi: 10.1006/anbe.1999.1314 
Rhodes, G. (2006). The evolutionary psychology of facial beauty. Annual Review of Psychology, 57, 199-226. doi: 10.1146/annurev.psych.57.102904.190208

Schaller, M. (2006). Parasites, behavioral defenses, and the social psychological mechanisms through which cultures are evoked. Psychological Inquiry, 17(2), 96-137. doi: $10.1207 /$ s15327965pli1702_2

Schniter, E., Gurven, M., Kaplan, H. S., Wilcox, N. T i Hooper, P. L. (2015). Skill ontogeny among Tsimane forager-horticulturalists. American Journal of Physical Anthropology, 158(1), 3-18. doi: 10.1002/ajpa.22757

Sell, A., Tooby, J i Cosmides, L. (2009). Formidability and the Logic of Human Anger. Proceedings of the National Academy of Sciences, 106(35), 15073-15078. doi: 10.1073/ pnas.0904312106

Shepardson, M. (1963). The traditional authority system of the Navajos. U: R. Cohen i J. Middleton (ur.), Comparative political systems: Studies in the politics of pre-industrial societies (str. 143-154). New York, NY: American Museum of Natural History.

Spisak, B. R., Homan, A. C., Grabo, A. i Van Vugt, M. (2012). Facing the situation: Testing a biosocial contingency model of leadership in intergroup relations using masculine and feminine faces. The Leadership Quarterly, 23(2), 273-280. doi: 10.1016/j. leaqua.2011.08.006

Spisak, B.R., Grabo, A., Arvey, R. i Van Vugt, M. (2014). The age of exploration and exploitation: Younger looking leaders endorsed for change and older looking leaders endorsed for stability. The Leadership Quarterly, 25(5), 805-816. doi: 10.1016/j. leaqua.2014.06.001

Stulp, G., Buunk, A. P., Verhulst, S. i Pollet, T. V. (2013). Tall claims? Sense and nonsense about the importance of height of US presidents. The Leadership Quarterly, 24(1), 159171. doi: 10.1016/j.leaqua.2012.09.002

Tajfel, H., Billig, M. G., Bundy, R. P. i Flament, C. (1971). Social categorization and intergroup behaviour. European journal of social psychology, 1(2), 149-178. doi: 10.1002/ ejsp.2420100307

Tigue, C. C., Borak, D. J., O’Connor, J. J., Schandl, C. i Feinberg, D. R. (2012). Voice pitch influences voting behavior. Evolution and Human Behavior, 33(3), 210-216. doi: 10.1016/j.evolhumbehav.2011.09.004

Todorov, A., Mandisodza, A. N., Goren, A. i Hall, C. C. (2005). Inferences of competence from faces predict election outcomes. Science, 308(5728), 1623-1626. doi: 10.1126/ science. 1110589

Tooby, J. i Cosmides, L. (1990). The past explains the present: Emotional adaptations and the structure of ancestral environments. Ethology and sociobiology, 11(4-5), 375-424. doi: 10.1016/0162-3095(90)90017-z

Tooby, J. i Cosmides, L. (2005). Conceptual foundations of evolutionary psychology. U: D. Buss (ur.), The Handbook of Evolutionary Psychology (str. 5-67). Hoboken, NJ: John Wiley and Sons. doi: 10.1002/9780470939376.ch1

Tooby, J., i Cosmides, L. (1992). The psychological foundations of culture. U: J. H. Barkow, L. Cosmides i J. Tooby (ur.), The Adapted Mind: Evolutionary Psychology and the Generation of Culture (str. 19-136). New York, NY: Oxford University Press. 
Van Vugt, M. i Ahuja, A. (2010). Selected: Why some people lead, why others follow, and why it matters. London, United Kingdom: Profile Books.

Van Vugt, M. i De Cremer, D. (1999). Leadership in social dilemmas: The effects of group identification on collective actions to provide public goods. Journal of personality and social psychology, 76(4), 587. doi: 10.1037/0022-3514.76.4.587

Van Vugt, M. i Kurzban, R. (2007). Cognitive and Social Adaptations for Leadership and Followership: Evolutionary Game Theory and Group Dynamics. U: J. P. Forgas, M. G. Haselton i W. von Hippel (ur.), Evolution and the Social Mind: Evolutionary Psychology and Social Cognition (str. 229- 244). New York, NY: Psychology Press.

Van Vugt, M., De Cremer, D. i Janssen, D. P. (2007). Gender differences in cooperation and competition: The male-warrior hypothesis. Psychological Science, 18(1), 19-23. doi: 10.1037/e554382012-018

Van Vugt, M., Hogan, R. i Kaiser, R.B. (2008). Leadreship, followership and evolution: Some lessions from the past. American Psychologist, 63(3), 182-196. doi: 10.1037/0003066x.63.3.182

Van Vugt, M., Jepson, S. F., Hart, C. M. i De Cremer, D. (2004). Autocratic leadership in social dilemmas: A threat to group stability. Journal of experimental social psychology, 40(1), 1-13. doi: 10.1016/s0022-1031(03)00061-1

Van Vugt, M., Johnson, D., Kaiser, R. i O'Gorman, R. (2008). Evolution and the social psychology of leadership: the mismatch hypothesis. U: C.L. Hoyt, G.R. Goethals i D.R. Forsyth (ur.): Leadership at the Crossroads: Psychology and Leadership, Vol. 1 (str. 262-282). Westport, CT: Praeger.

Vandermassen, G. (2008). Can Darwinian feminism save female autonomy and leadership in egalitarian society? Sex Roles, 59(7-8), 482-491. doi: 10.1007/s11199-008-9478-3

von Frisch, K. (1967). The dance language and orientation of bees. Cambridge, MA: Harvard University Press.

von Rueden, C. i Gurven, M. (2012). When the strong punish: Why net costs of punishment are often negligible. Behavioral and Brain Sciences, 35(1),43-44. doi: 10.1017/ s0140525x11001427

von Rueden, C. i Van Vugt, M. (2015). Leadership in small-scale societies: Some implications for theory, research, and practice. The Leadership Quarterly, 26(6), 978-990. doi: 10.1016/j.leaqua.2015.10.004

von Rueden, C., Gurven, M. i Kaplan, H. (2008). The multiple dimensions of male social status in an Amazonian society. Evolution and Human Behavior, 29(6), 402-415. doi: 10.1016/j.evolhumbehav.2008.05.001

von Rueden, C., Gurven, M. i Kaplan, H. (2010). Why do men seek status? Fitness payoffs to dominance and prestige. Proceedings of the Royal Society of London B: Biological Sciences, rspb20102145. doi: 10.1098/rspb.2010.2145

von Rueden, C., Gurven, M., Kaplan, H. i Stieglitz, J. (2014). Leadership in an egalitarian society. Human Nature, 25(4),538-566. doi: 10.1007/s12110-014-9213-4

White, A. E., Kenrick, D. T. i Neuberg, S. L. (2013). Beauty at the ballot box: Disease threats predict preferences for physically attractive leaders. Psychological Science, 24(12), 2429-2436. doi: 10.1177/0956797613493642 
Willer, R. (2009). Groups reward individual sacrifice: The status solution to the collective action problem. American Sociological Review, 74(1), 23-43. doi: 10.1177/000312240907400102

Wright, J., Stone, R. E. i Brown, N. (2003). Communal roosts as structured information centres in the raven, Corvus corax. Journal of Animal Ecology, 72(6), 1003-1014. doi: 10.1046/j.1365-2656.2003.00771.x

Xue, Y., Wang, Q., Long, Q., Ng, B. L., Swerdlow, H., Burton, J. i MacArthur, D. G. (2009). Human $\mathrm{Y}$ chromosome base-substitution mutation rate measured by direct sequencing in a deep-rooting pedigree. Current Biology, 19(17), 1453-1457. doi: 10.1016/j. cub.2009.07.032

Yanca, C. i Low, B. S. (2004). Female allies and female power: A cross-cultural analysis. Evolution and Human Behavior, 25(1), 9-23. doi: 10.1016/s1090-5138(03)00065-5

\title{
THE ORIGIN OF LEADERSHIP: EVOLUTIONARY VIEW OF THE RELATIONSHIP BETWEEN LEADERS AND THEIR FOLLOWERS
}

\begin{abstract}
Summary
Leadership is present across different formal and informal human groups. So far, social sciences such as economy, political science, and psychology dealt with this issue. Research in this field was mainly aimed at the description of leadership, and was focused on leaders. Recently, evolutionary reasoning has been applied to research in the field, shifting the focus of research towards the emergence of leadership. This approach emphasizes the adaptive value of leadership which benefits both leaders and followers, who form the majority of the population. Within evolutionary leadership theory, it is assumed that the leader-follower relationship is an adaptation formed during evolutionary history that solved the problem of group coordination. Three lines of research will be presented in this review. First, different forms of leadership among animal groups across various species, ranging from insects to primates, are discussed. Second, anthropological evidence of leadership among modern hunter-gatherer societies, whose life-style resembles those of early humans, will be presented. Finally, evidence of evolutionary mismatch, indicating that people still show preferences for characteristics that indicated good leadership skills in ancestral times, but not nowadays, will be provided.
\end{abstract}

Keywords: Evolutionary psychology, evolutionary leadership theory, hunter-gatherers, animals, evolutionary mismatch, followership

Primljeno: 16. 11. 2018. 
